\title{
HIV triggers immunoregulatory dendritic cells and regulatory $T$ cells through the non-canonical NF-kB pathway
}

\author{
O Manches ${ }^{1 *}$, MV Fernandez ${ }^{1}$, J Plumas ${ }^{2}$, L Chaperot $^{2}$, N Bhardwaj $^{1}$ \\ From AIDS Vaccine 2012 \\ Boston, MA, USA. 9-12 September 2012
}

\section{Background}

HIV stimulates plasmacytoid dendritic cell (pDC) through TLR7 and induce the secretion of high levels of IFNa. pDC stimulated by HIV also upregulate the expression of the enzyme indoleamine 2,3 dioxygenase (IDO). IDO is critical for the induction of regulatory $\mathrm{T}$ cells (Treg) by HIV-activated pDC. We investigated the molecular mechanisms of IDO induction and its consequences for Treg function.

\section{Methods}

The cells used were purified primary pDC and the GEN pDC cell line. A combination of siRNA knock-down, immunoprecipitation of TLR signaling pathway molecules, IDO promoter engineering and chromatin immunoprecipitation was used to determine the molecular mechanisms of IDO induction in pDC. To analyze Treg function and interaction with conventional DC (cDC), blocking antibodies to CTLA- 4 and CTLA-4-Ig were used.

\section{Results}

We demonstrate that HIV induces activation of the non-canonical NF-kB pathway in $\mathrm{pDC}$, and is essential for IDO induction. TLR7 triggering induces recruitment of TRAF3 to the TLR-MyD88 complex, followed by release of NIK and phosphorylation of IKK $\alpha$. Activation of the non-canonical NF- $\kappa \mathrm{B}$ pathway culminates in p52/RelB nuclear translocation and binding to the IDO promoter.

Furthermore, IDO-expressing pDC trigger the generation of Treg, which dampen $\mathrm{CDC}$ activation through CTLA-4. CTLA-4 also induces IDO expression in cDC

${ }^{1} \mathrm{NYU}$ Cancer Institute, New York City, NY, USA

Full list of author information is available at the end of the article in a NIK-dependent fashion, allowing $\mathrm{cDC}$ to induce Treg from naïve CD4+ T cells.

\section{Conclusion}

The non-canonical NF-kB pathway plays a central role in regulating IDO expression in $\mathrm{pDC}$ and $\mathrm{cDC}$ upon HIV infection, and may be a potential target for regulating Treg activity in chronic or acute HIV infection.

\section{Author details}

'NYU Cancer Institute, New York City, NY, USA. ${ }^{2}$ Inserm, U823,

Immunobiologie et Immunotherapie des Cancers, La Tronche, France.

Published: 13 September 2012

doi:10.1186/1742-4690-9-S2-P184

Cite this article as: Manches et al:: HIV triggers immunoregulatory dendritic cells and regulatory T cells through the non-canonical NF-kB pathway. Retrovirology 2012 9(Suppl 2):P184.

Submit your next manuscript to BioMed Central and take full advantage of:

- Convenient online submission

- Thorough peer review

- No space constraints or color figure charges

- Immediate publication on acceptance

- Inclusion in PubMed, CAS, Scopus and Google Scholar

- Research which is freely available for redistribution 